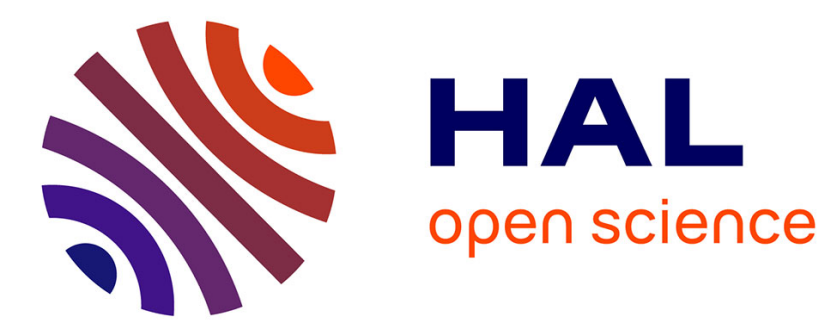

\title{
The Belgian supercontainer concept: Study of the concrete buffer behaviour in service life
}

\author{
Stéphane Poyet
}

\section{To cite this version:}

Stéphane Poyet. The Belgian supercontainer concept: Study of the concrete buffer behaviour in service life. Journal de Physique IV Proceedings, 2006, Corrosion and Long Term Performance of Concrete in NPP and Waste Facilities, 136, pp.167-175. 10.1051/jp4:2006136018 . cea-01272807

\section{HAL Id: cea-01272807 https://hal-cea.archives-ouvertes.fr/cea-01272807}

Submitted on 11 Feb 2016

HAL is a multi-disciplinary open access archive for the deposit and dissemination of scientific research documents, whether they are published or not. The documents may come from teaching and research institutions in France or abroad, or from public or private research centers.
L'archive ouverte pluridisciplinaire HAL, est destinée au dépôt et à la diffusion de documents scientifiques de niveau recherche, publiés ou non, émanant des établissements d'enseignement et de recherche français ou étrangers, des laboratoires publics ou privés. 
J. Phys. IV France 136 (2006) 167-175

(C) EDP Sciences, Les Ulis

DOI: $10.1051 /$ jp4:2006136018

\title{
The Belgian supercontainer concept: Study of the concrete buffer behaviour in service life
}

\section{S. Poyet ${ }^{1}$}

${ }^{1}$ CEA Saclay, DENIDANSIDPCISCCMEILECBA B158, 91191 Gif-sur-Yvette, France

\begin{abstract}
The ONDRAF/NIRAS agency for radioactive waste and enriched fissile materials is in charge of the management of the radioactive wastes in Belgium. In the framework of the study of a new concept for the disposal of high level wastes, a project of a supercontainer has been considered and studied. The main goal of this study was to estimate the Thermo-Hydrological behaviour of the concrete buffer in service life. Water (liquid and vapour) and heat transfers were described through coupled differential equations by the means of the procedure THYDR developed at the Department of Physico-Chemistry of the French Commission for Atomic Energy (CEA/DPC) and implemented in the code CAST3M. Two different configurations for the concrete buffer were investigated: concrete cured with no water loss or partially dried. The simulations allowed the estimation of the evolution of both vapour pressure and liquid saturation.
\end{abstract}

\section{INTRODUCTION}

The ONDRAF/NIRAS agency for radioactive waste and enriched fissile materials is in charge of the management of the radioactive wastes in Belgium. In the framework of the study of a new concept for the disposal of vitrified High Level Wastes (HLW), a project of a supercontainer has been considered. It is composed of a cylindrical concrete buffer containing two radioactive waste canisters which are emplaced within galleries in the Boom Clay (Figure 1).

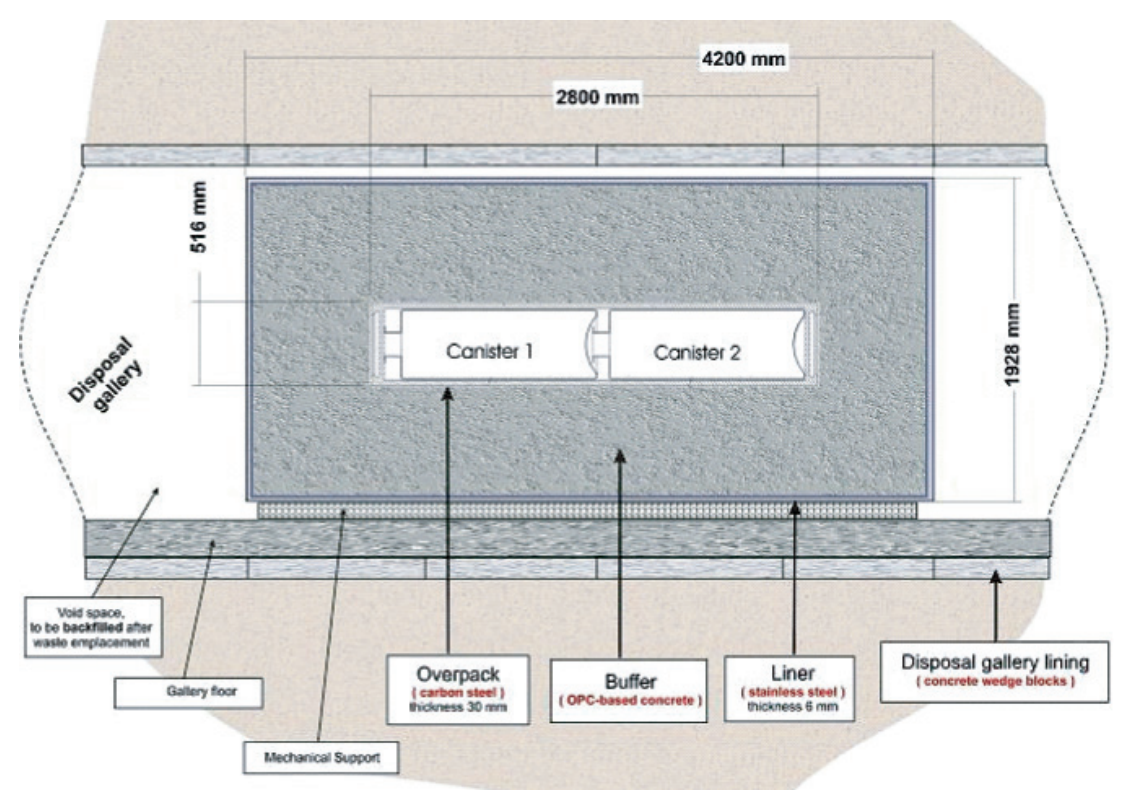

Figure 1. Schematic diagram illustrating the geometry and the dimensions of the supercontainer emplaced in concrete galleries in the Boom Clay. 
A first phase of work was conducted in 2004 in order to identify key issues associated with the supercontainer design [1] and define areas that were investigated during the second phase. For instance, the effect of radiolysis (and consequent generation of hydrogen) and the change in the profile of water content in the supercontainer concrete buffer during heating were indentified as key uncertainties [2]. Calculations of the gas generation due to gamma radiolysis and the Thermo-Hydrological evolution in the concrete buffer (in particular at the vicinity of the overpack) were then undertaken at the CEA/DPC [3][4]. This paper presents the methodology and the results of the latter simulations.

\section{OVERVIEW OF THE TH MODELLING}

The modelling involves the description of coupled heat and water (liquid and vapour) transfers in concretes submitted to high temperatures [5]. The solid skeleton and the liquid water are assumed incompressible. It is also assumed that the fraction of dry air is negligible in front of the fraction of vapour (this is relevant for high temperatures). The mass conservation equations for vapour and liquid water ( $m_{v}$ and $m_{l}$ respectively) are:

$$
\begin{gathered}
\frac{\partial m_{v}}{\partial t}=-\operatorname{div}\left(\underline{w}_{v}\right)+\mu_{l \rightarrow v}=\frac{\partial}{\partial t}\left[\rho_{v}\left(p_{v}, T\right) \phi(d)\left(1-S_{l}\right)\right] \\
\frac{\partial m_{l}}{\partial t}=-\operatorname{div}\left(\underline{w}_{l}\right)-\mu_{l \rightarrow v}+\dot{d}(T)=\frac{\partial}{\partial t}\left[\rho_{l}(T) \phi(d) S_{l}\right]
\end{gathered}
$$

where $\mu_{l \rightarrow v}$ stands for the amount of liquid water that turns into vapour, $\phi$ is the porosity, $\rho_{v}$ and $\rho_{l}$ are the density of vapour and liquid water respectively, $S_{l}$ is the liquid saturation. The source term $d$ in eq. (2) stands for the amount of water released by the dehydration of the concrete hydrates in relation to the temperature elevation. The transfers of liquid water and vapour are assumed to be governed by Darcy's law (no diffusion). The flux of each phase (vapour $\underline{w}_{v}$ and water $\underline{w}_{l}$ ) is then given by:

$$
\forall i \in\{l, v\} \quad \underline{w}_{i}=-\frac{\rho_{i}}{\eta_{i}} K_{i}(d) k_{r i}\left(S_{l}\right) \underline{\operatorname{grad}}\left(p_{i}\right)
$$

where $\eta_{i}$ and $p_{i}$ stand for the dynamic viscosity and the pressure of the phase $i$ (liquid or vapour). $K_{i}$ is the intrinsic permeability of the porous medium for each phase, for a given material it only depends on the amount of dehydrated water $d . k_{r i}$ is the relative permeability to the phase $i$, it only depends on the saturation $S_{l}$. The liquid pressure $p_{l}$ is given by the Kelvin-Laplace equation:

$$
p_{l}\left(p_{v}, T\right) \approx-p_{c}=\rho_{l}(T) \frac{R T}{M_{w}} \ln \left(\frac{p_{v}}{p_{v s}}\right)
$$

The assumption of the piecewise linearity of the desorption isotherm allows merging eqs. (1-4) into eq. (5) in which the only unknown quantities are the saturation $S_{l}$ and temperature $T$ :

$$
\left\{\begin{array}{l}
{\left[\rho_{l}(T)-\rho_{v}\left(p_{v}, T\right)\right] \phi(d) \frac{\partial S_{l}}{\partial t}=\operatorname{div}\left[D\left(S_{l}, T, d\right) \underline{\operatorname{grad}}\left(S_{l}\right)\right]+\dot{d}(T)} \\
D\left(S_{l}, T, d\right)=\left[\frac{1}{S_{l}} \frac{\rho_{l}^{2}}{\rho_{v} \eta_{l}}(T) K_{l}(d) k_{r g}\left(S_{l}\right)+\frac{\rho_{v}}{\eta_{v}}(T) K_{v}(d) k_{r v}\left(S_{l}\right)\right] \frac{\partial p_{v}}{\partial S_{l}}
\end{array}\right.
$$

This equation describes the coupled transfers of both vapour and water. The description of heat transfers is classically done using eq. (6).

$$
C(T) \frac{\partial T}{\partial t}=\operatorname{div}\left[\lambda\left(S_{l}, d\right) \underline{\operatorname{grad}}(T)\right]-L_{l \rightarrow v}(T) \mu_{l \rightarrow v}-L_{s \rightarrow l} \dot{d}(T)
$$

where $\lambda$ and $C(T)$ are the thermal conductivity and capacity respectively. The terms $L_{l \rightarrow v}$ and $L_{s \rightarrow l}$ stand for the latent heat of vaporisation and dehydration respectively. The equations (5) and (6) allow the description of coupled water (liquid and vapour) and heat transfers within concretes submitted to high temperatures. This modelling has been implemented within the Finite Element code CAST3M 
under the form of a subroutine called THYDR [5]. It allows the evaluation of temperature, saturation, dehydration, porosity increase and pressure for each phase within concrete structures.

\section{SIMULATIONS}

\subsection{Configuration and methodology}

Two different scenarios were considered for the concrete buffer: $\mathrm{S} 1$ - concrete cured at $20^{\circ} \mathrm{C}$ (initial saturation around 0.81) and use of portlandite as filler between the overpack and the concrete buffer (Figure 1) and S2 - concrete partially dried at $60^{\circ} \mathrm{C}$ (initial saturation around 0.17 ) and use of lime as filler.

The THYDR subroutine is meant for application to only one concrete. Therefore, the calculations proceeded in three stages:

1. thermal calculation of the storage (from the overpack, across the supercontainer into the Boom clay),

2. extraction of the temperature evolutions at the boundaries of the concrete buffer,

3. coupled Thermo Hydrological calculation of the buffer alone using the temperatures determined in point 1 as the boundary conditions.

\subsection{Thermal calculation of temperature profile}

A cross section (in axisymmetric conditions) of the storage (from the overpack, across the supercontainer and into the Boom clay) was modelled (Figure 2). Boundary conditions of $100^{\circ} \mathrm{C}$ and $16^{\circ} \mathrm{C}$ at the inner surface of the overpack and in the Boom clay were imposed respectively $\left(16^{\circ} \mathrm{C}\right.$ is the initial temperature within the Boom clay and $100^{\circ} \mathrm{C}$ is the specified maximal temperature which can be applied on the inner surface of the overpack due to the thermal power of the radioactive waste). The initial temperature is assumed uniform and equal to $16^{\circ} \mathrm{C}$. Two calculations corresponding to the two scenarios considered were done (a mesh including 240 eight node quadrangles was used). The input data (from [2]) of the calculations are given in Table 1.

Figure 3 presents the estimated temperature evolution within the concrete buffer and at the (internal and external) boundaries of the concrete buffer. Due to the imposed condition $\left(100^{\circ} \mathrm{C}\right.$ at the inner surface of the overpack) the temperature increase at the internal surface of the concrete buffer is fast $\left(90^{\circ} \mathrm{C}\right.$ reached after 1 month). The temperature increase at the external surface is delayed and lower. The resulting temperature gradient between the internal and external surfaces of the buffer reaches $50^{\circ} \mathrm{C}$ at the beginning of the heating and eventually falls to $15^{\circ} \mathrm{C}$ after ten years. As expected, due to the

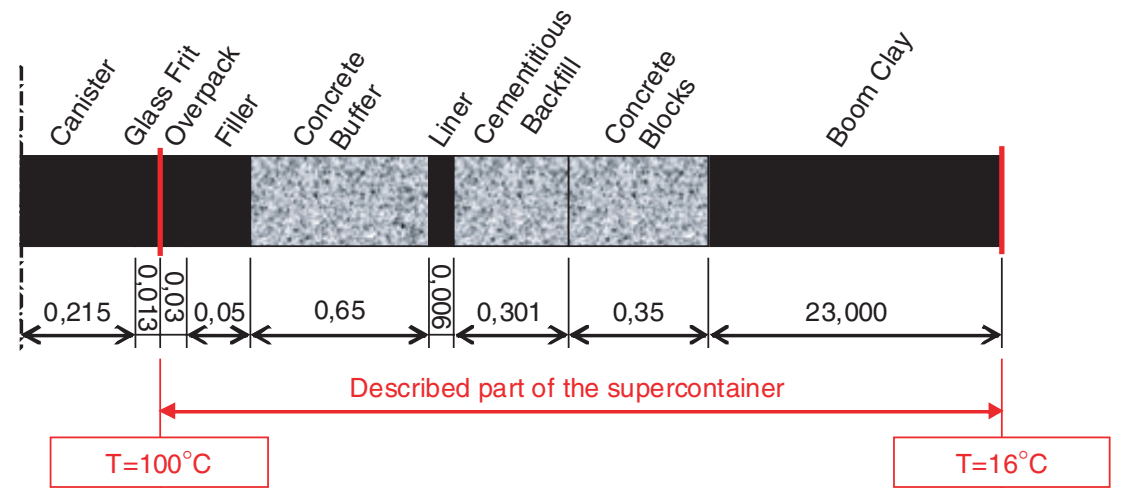

Figure 2. Profile and boundary conditions used in the thermal calculation to estimate the temperature evolution at the boundaries of the concrete buffer (thicknesses are in meters). 
Table 1. Input data used for the thermal calculations (from [2]).

\begin{tabular}{|l|l|l|l|}
\hline Material & Cond. $[\mathrm{W} / \mathrm{mK}]$ & Density $\left[\mathrm{kg} / \mathrm{m}^{3}\right]$ & Capacity $[\mathrm{J} / \mathrm{kgK}]$ \\
\hline Carbon steel overpack & 76.0 & 7850 & 4800 \\
Portlandite (filler - S1) & 1.0 & 500 & 1000 \\
Lime (filler - S2) & 1.0 & 1000 & 1000 \\
Buffer concrete (S1) & 2.7 & 2378 & 1000 \\
Buffer concrete (S2) & 2.3 & 2304 & 1000 \\
Stainless steel liner & 16.1 & 8000 & 500 \\
Cementitious backfill & 1.0 & 2300 & 1000 \\
Gallery concrete & 1.5 & 2345 & 768 \\
Boom clay & 1.7 & 2000 & 1400 \\
\hline
\end{tabular}

(a)

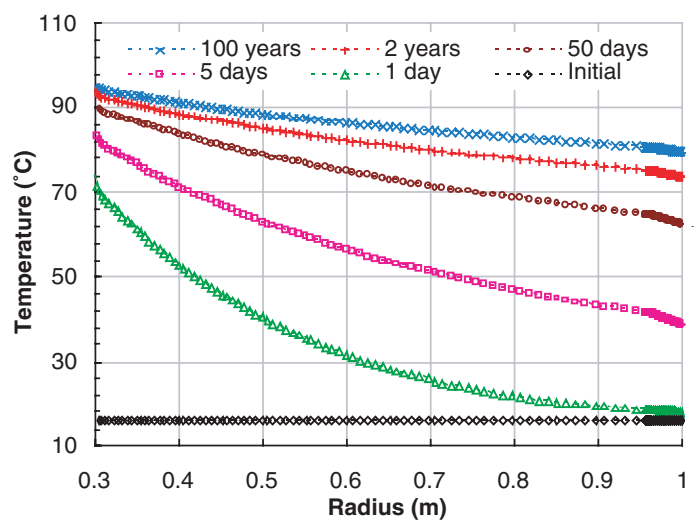

(b)

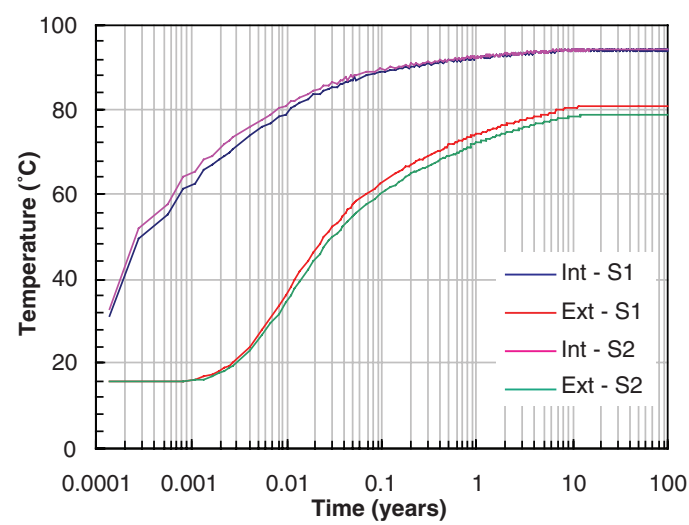

Figure 3. Results from the thermal calculations, estimation of the temperature evolution within the concrete buffer (a) and at its boundaries (b).

thinness of the filler layer and the slight difference in the thermal properties of the buffer concrete for both scenarios, there is hardly any difference between the results of both scenarios (around $1{ }^{\circ} \mathrm{C}$ ).

\subsection{Coupled Thermo-Hydrological calculation}

A T-H calculation was then undertaken on the concrete buffer alone using the mesh depicted in Figure 4 (100 eight node quadrangles were used in axisymmetric conditions). The initial conditions were: uniform temperature $\left(16^{\circ} \mathrm{C}\right)$ and uniform saturation $(0.81$ and 0.17 for scenario $\mathrm{S} 1$ and $\mathrm{S} 2$ respectively) within the buffer. The boundary conditions were: no water exchange to the outside of the buffer (because of the liner and the overpack) and imposed temperature at the external and internal surface of the buffer as shown in Figure 3 for each scenario.

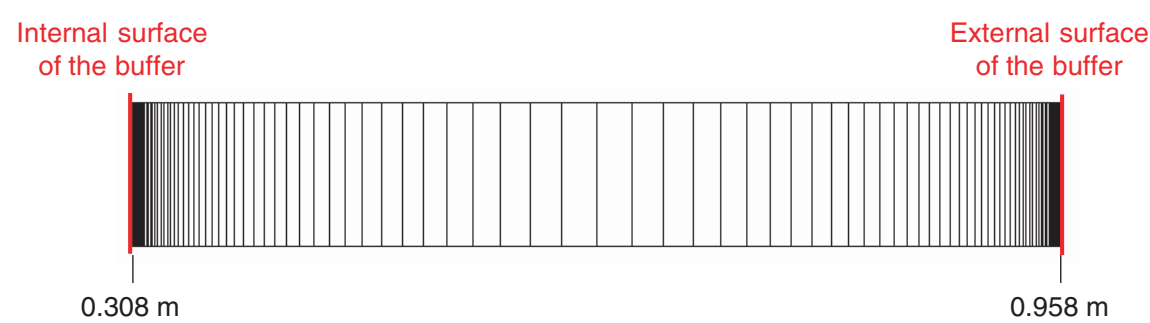

Figure 4. Illustration of the mesh used for the T-H calculations. 
All the data needed for the T-H calculations were either derived from the experimental results from Gallé and Sercombe [6] or estimated through theoretical analysis [5] (all the numerical values are given in Table 2). For instance, the evolution of the heat capacity of the concrete $C\left(S_{l}, d, T\right)$ as a function of saturation $S_{l}$, dehydration $d$ and temperature $T$ was estimated using elementary homogenisation:

$$
C\left(S_{l}, d, T\right)=\left[\frac{C_{c} m_{c}+C_{a} m_{a}}{m_{c}+m_{a}}\right]+\phi(d) \rho_{l}(T) S_{l} C_{f w}-d(T) C_{b w}
$$

where $m_{c}$ and $m_{a}$ are the amounts of cement and aggregates per $\mathrm{m}^{3}$ of concrete, $C_{c}, C_{a}, C_{f w}$ and $C_{b w}$ stand for the specific heat capacity of cement, aggregates, free and bound water respectively. The evolution of the heat conductivity as a function of saturation and dehydration was fitted on experimental results and is given by (the heat conductivity of the saturated, dry and dehydrated concrete was characterised [6]):

$$
\lambda\left(S_{l}, d\right)=\left[\lambda_{d}+\frac{S_{l}}{S_{l 0}}\left(\lambda_{0}-\lambda_{d}\right)\right]-k_{\lambda} d(T)
$$

where $\lambda_{d}$ is the conductivity of dry concrete, $\lambda_{0}$ is the conductivity related to the initial saturation $S_{l 0}$ and $k_{\lambda}$ is a positive coefficient. The evolution law of the intrinsic permeability for each phase (water and vapour) was also identified using experimental results (measurements of gas permeability on the dehydrated concrete $[5,6])$ :

$$
\forall i \in\{l, v\} \quad K_{i}(d)=K_{i 0} \exp (\alpha d)
$$

where $K_{i 0}$ and $\alpha$ are the initial (corresponding to non-dehydrated concrete) intrinsic permeability to the phase $i$ (liquid water $l$ or vapour $v$ ) and a positive coefficient respectively. The relative permeability to liquid water $k_{r l}$ and vapour $k_{r v}$ follows the equations proposed by Van Genuchten [7]. The value of the exponent $m$ was fitted on the experimental results from Villain et al. [8].

$$
k_{r g}\left(S_{l}\right)=\sqrt{1-S_{l}}\left(1-S_{l}^{1 / m}\right)^{2 m} \quad k_{r l}\left(S_{l}\right)=\sqrt{S_{l}}\left[1-\left(1-S_{l}^{1 / m}\right)^{m}\right]^{2}
$$

Table 2. Input data for the T-H calculations (from [5] and [6], values of $C_{a}$ and $C_{c}$ are from [9]).

\begin{tabular}{|l|l|l|l|}
\hline Input data & Symbol & Value & Unity \\
\hline Quantity of cement in the concrete & $m_{c}$ & 350 & $\mathrm{~kg} / \mathrm{m}^{3}$ \\
Quantity of aggregates in the concrete & $m_{a}$ & 1950 & $\mathrm{~kg} / \mathrm{m}^{3}$ \\
Initial porosity & $\phi_{0}$ & 10.4 & $\%$ \\
Initial intrinsic permeability to gas & $K_{v 0}$ & $2.3 \cdot 10^{-17}$ & $\mathrm{~m}^{2}$ \\
Initial intrinsic permeability to water & $K_{l 0}$ & $2.3 \cdot 10^{-21}$ & $\mathrm{~m}^{2}$ \\
Permeability increase coefficient & $\alpha$ & 0.126 & $\mathrm{~m}^{3} / \mathrm{kg}$ \\
Initial heat conductivity (S1) & $\lambda_{01}$ & 2.7 & $\mathrm{~W} / \mathrm{mK}$ \\
Initial heat conductivity (S2) & $\lambda_{02}$ & 2.3 & $\mathrm{~W} / \mathrm{mK}$ \\
Heat conductivity of dry concrete & $\lambda_{d}$ & 2.2 & $\mathrm{~W} / \mathrm{mK}$ \\
Heat conductivity coefficient & $k_{\lambda}$ & $7.88 \cdot 10^{-3}$ & $\mathrm{Wm}{ }^{2} / \mathrm{kgK}$ \\
Dehydration coefficient & $k_{d}$ & 0.136 & $\mathrm{~kg} / \mathrm{m}^{3} \mathrm{~K}$ \\
Mean hydrates density & $\rho_{d}$ & 2.28 & $\mathrm{~g} / \mathrm{cm}^{3}$ \\
Exponent for Van Genuchten laws & $m$ & 0.5 & - \\
Initial saturation for scenario S1 & $S_{l 0}$ & 0.81 & - \\
Initial saturation for scenario S2 & $S_{l 0}$ & 0.17 & - \\
Latent heat of dehydration & $L_{s \rightarrow l}$ & 2500 & $\mathrm{~kJ} / \mathrm{kg}$ \\
Specific heat capacity - aggregates & $C_{a}$ & 800 & $\mathrm{~J} / \mathrm{kgK}$ \\
Specific heat capacity - cement & $C_{c}$ & 750 & $\mathrm{~J} / \mathrm{kgK}$ \\
Specific heat capacity - free water & $C_{f w}$ & 4.18 & $\mathrm{~kJ} / \mathrm{kgK}$ \\
Specific heat capacity - bound water & $C_{b w}$ & 3.76 & $\mathrm{~kJ} / \mathrm{kgK}$ \\
\hline
\end{tabular}


Dehydration was assumed to depend only on temperature $T$ and to take place at $60^{\circ} \mathrm{C}$ [5]. The coefficient $k_{d}$ was identified using experimental results [6].

$$
d(T)=\left\{\begin{array}{l}
k_{d}(T-60) \text { if } T>60^{\circ} \mathrm{C} \\
0 \quad \text { else }
\end{array}\right.
$$

The increase in porosity $\phi$ was directly related to the amount of water released by dehydration $d[5]$ :

$$
\phi(d)=\phi_{0}+\frac{d(T)}{\rho_{d}}
$$

where $\rho_{d}$ is the mean value of the density of hydrates and $\phi_{0}$ is the initial porosity.

The results of the T-H calculations are given below. The temperature evolutions within the concrete buffer for the two considered scenarios S1 (no drying) and S2 (partial drying at $60^{\circ} \mathrm{C}$ ) estimated by the $\mathrm{T}-\mathrm{H}$ simulation are presented in Figure 5. The difference in the concrete properties for both scenarios has hardly any influence on the heat transfers. The evolution for the scenario S2 (partial drying at $60^{\circ} \mathrm{C}$ ) is almost the same (the maximal difference between the two of them is about $1^{\circ} \mathrm{C}$ ). In addition there is almost no difference between the temperature evolutions estimated by both thermal and T-H calculations (Figure 3). In fact, the temperature imposed $\left(100^{\circ} \mathrm{C}\right.$ at the inner surface of the overpack) is not high enough to induce the change of phase of the liquid water and thus does not have a great influence on the heat transfers.

The temperature increase within the concrete buffer induces the degradation of the concrete hydrates and the release of water which amount is estimated using eq. (11). It induces the increase of the porosity of the concrete according to eq. (12). These results are presented on Figure 6 for the scenario S1 (the results for the scenario S2 are the same). The maximal amount of released water (about $10 \mathrm{~kg} / \mathrm{m}^{3}$ ) can be found at the inner surface of the buffer (where the temperature is the highest) after 100 years. At the other side of the buffer the amount is about $3 \mathrm{~kg} / \mathrm{m}^{3}$ due to the lesser temperature. The corresponding increases of porosity are small $(0.45 \%$ and $0.15 \%$ for the inner and outer surfaces of the buffer respectively). The two sets of curves are similar because they are conditioned by the temperature evolution.

The overpressures induced by the heating for the two scenarios increase with time (following the temperature evolution), nevertheless they remain small (Figure 7). The maximal overpressures can be found at the inner surface of the concrete buffer with the highest temperatures. They are about 0.07 and

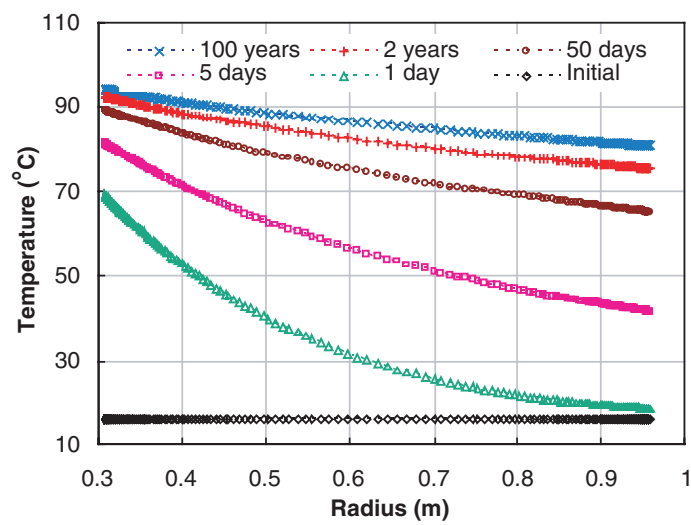

(a)

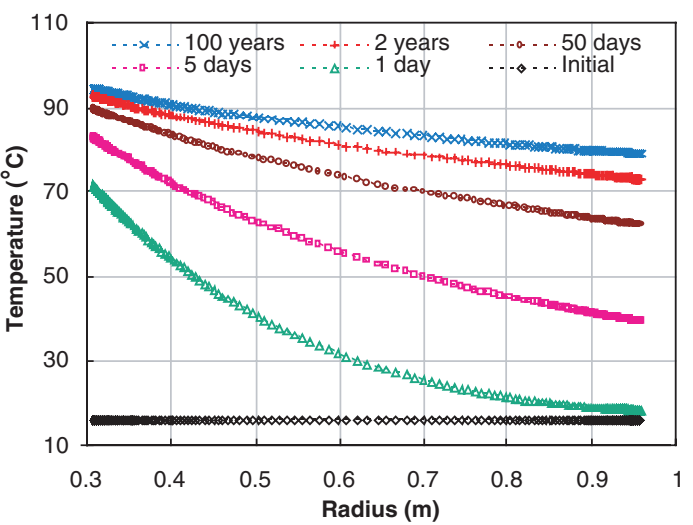

(b)

Figure 5. Evolution of the temperature within the supercontainer for the scenarios $\mathrm{S} 1$ (cure at $20^{\circ} \mathrm{C}$ - a) and $\mathrm{S} 2$ (partial drying at $60^{\circ} \mathrm{C}-\mathrm{b}$ ). 


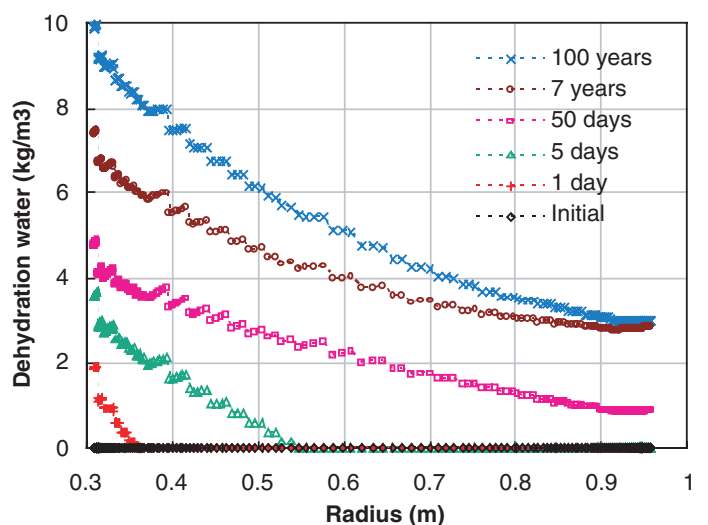

(a)

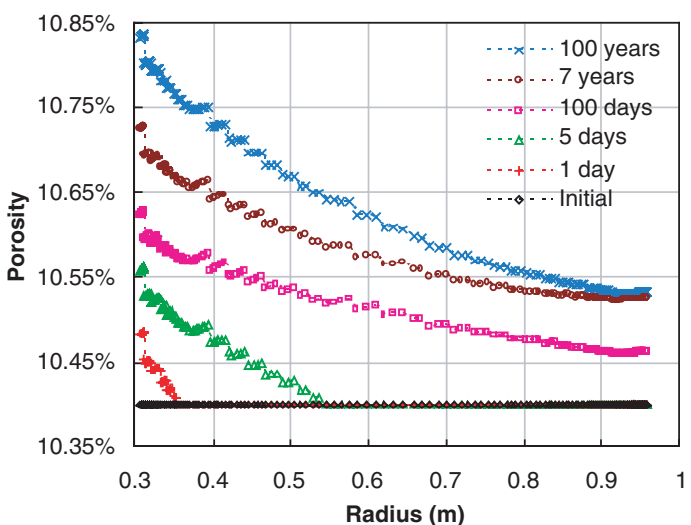

(b)

Figure 6. Estimation of the amount of water released by dehydration (a) and the induced increase of porosity (b) within the concrete buffer for the scenario S1.

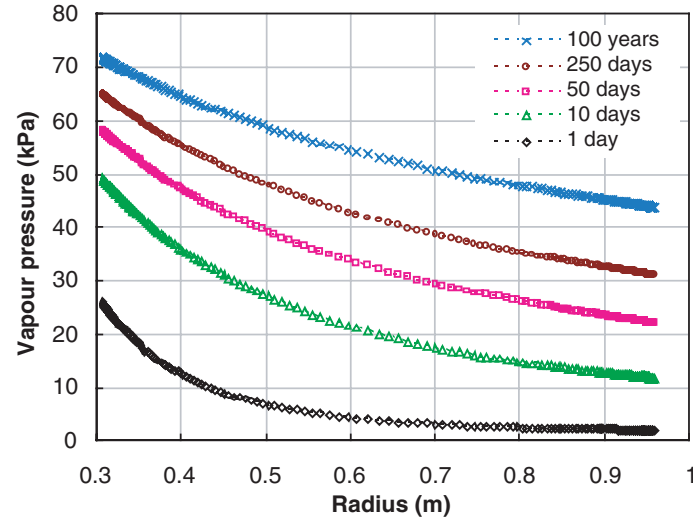

(a)

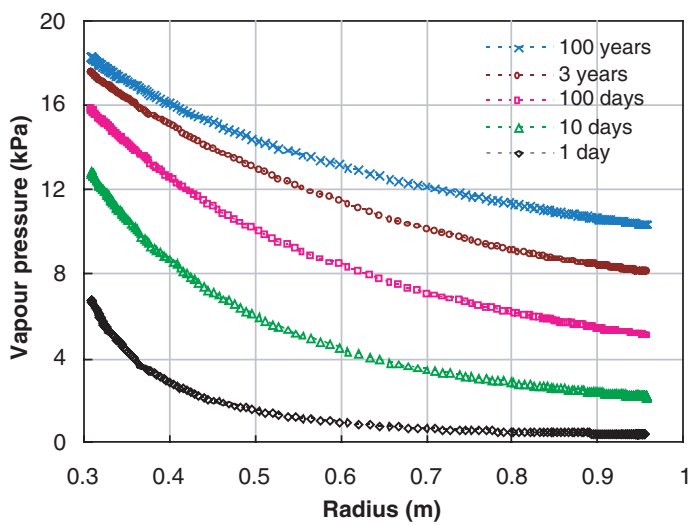

(b)

Figure 7. Estimation of the vapour pressure within the buffer for the scenario S1 (a) and S2 (b).

$0.02 \mathrm{MPa}$ for the scenarios $\mathrm{S} 1\left(\right.$ cure at $20^{\circ} \mathrm{C}$ ) and $\mathrm{S} 2$ (partial drying at $60^{\circ} \mathrm{C}$ ) respectively. These small increases are due to the low temperature imposed to the concrete buffer (less than $100^{\circ} \mathrm{C}$ ) leading to little vaporisation.

The release of water generates the increase of the liquid saturation. The maximal increase can be found next to the inner surface of the concrete buffer (where the temperature is the highest, Figure 5). The saturation gradient generates the transfer of water within the concrete buffer in order to return to equilibrium. The release of water leads to the increase of the liquid saturation at equilibrium from 0.81 and 0.17 to 0.87 and 0.22 for the scenarios S1 and S2 respectively (Figure 8). The small increase of the saturation is due to the low temperature imposed to the concrete buffer (leading to little water release) and to the slight increase of the porosity.

One can note the difference in the patterns of the saturation evolutions for the two scenarios considered (Figure 8): the relative variation of saturation at the inner surface of the buffer is greater for the scenario S2 (partial drying at $60^{\circ} \mathrm{C}$ ). This is due to the difference of the effective permeability 

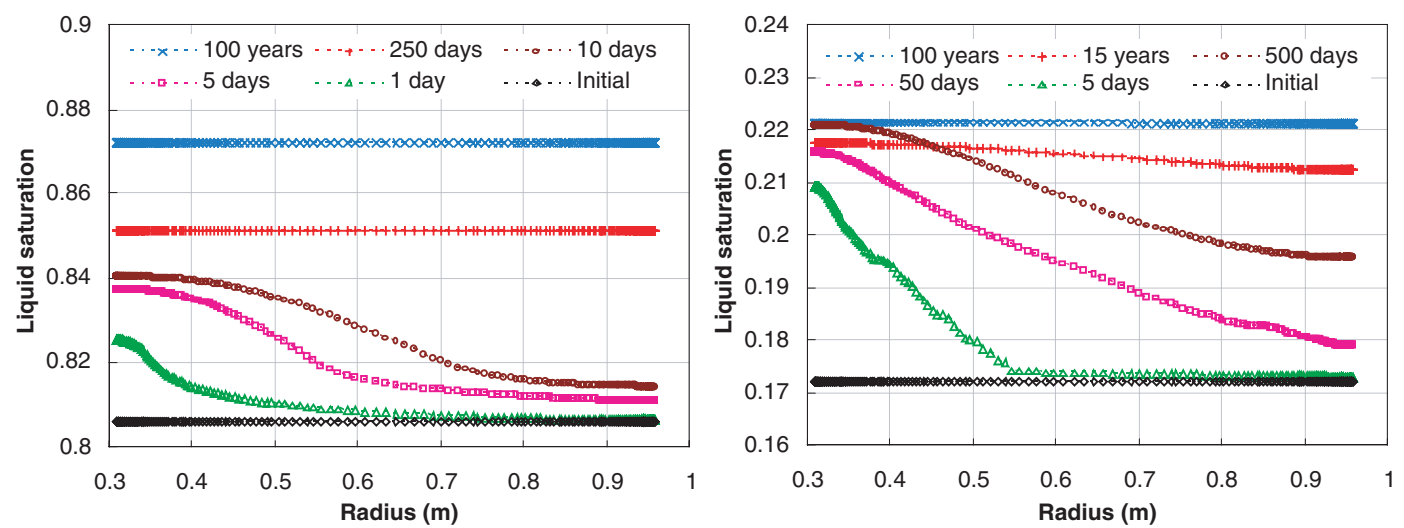

Figure 8. Estimation of the liquid saturation within the buffer for the scenario S1 (a) and S2 (b).

(product of the intrinsic and relative permeability in eq. (3)) corresponding to the difference of saturation for the two scenarios. Eq. (10) indicates that there are three orders of magnitude between the relative permeability to water for each scenario. It means that the water released near the inner surface of the buffer for the scenario S1 (saturation around 0.81) moves towards the other side of the buffer (in order to equilibrate the saturation within the buffer) mush faster than in the case of the scenario S2 (saturation around 0.17 ). The saturation increase at the inner surface of the buffer is then less important than for scenario S2.

\section{CONCLUSION}

In the framework of the study of a supercontainer concept for the disposal of Belgian HLW, calculations were carried out at the CEA/DPC in order to estimate the T-H evolution of the concrete buffer. The modelling used is implemented in the code CAST3M. It describes the transfers of heat and water (liquid and vapour) by the means of coupled differential equations.

Two scenarios were considered: S1- concrete cured at $20^{\circ} \mathrm{C}$ (initial saturation around 0.81 ) and use of portlandite as filler between the overpack and the concrete buffer and S2 - concrete partially dried at $60^{\circ} \mathrm{C}$ (initial saturation around 0.17 ) and use of lime as filler.

The temperature evolution at the boundaries of the buffer was estimated using a thermal calculation of the whole storage and was thereafter used as a boundary condition for the T-H calculation of the concrete buffer alone. A constant temperature of $100^{\circ} \mathrm{C}$ was imposed as a boundary condition, corresponding to the specified maximal value. A slight difference was found between the temperature evolutions resulting from both thermal and T-H calculations, indicating the small influence of the Hydrological part of the modelling on the thermal transfers. This is due to the low temperature imposed to the concrete buffer (less than $100^{\circ} \mathrm{C}$ ).

As a consequence of the low temperature imposed, the amount of water released and the porosity increase are small. This leads to a little augmentation of the saturation within the buffer. The overpressures induced by the generation of vapour for each scenario remain low (under $0.1 \mathrm{MPa})$.

\section{Acknowledgments}

The author would like to warmly thank R. Gens and J. bel (ONDRAF/NIRAS) for their financial and scientific support. 


\section{References}

[1] Crawford M.B. and Wickham S.M., "Workshop on the evolution of OPC buffer and steel corrosion in the Belgian supercontainer design for HLW disposal", Galson Sciences LTD Report 0427-2, (2004), 46p.

[2] Wickham S.M., Crawford M.B. and Bennett D.G., "Belgian supercontainer design for HLW and spent fuel disposal - Evaluation of the reference design", Galson Sciences LTD Report 0460-5, (2005), 98p.

[3] Bouniol P., "Gas generation due to gamma radiolysis in the concrete of a supercontainer for HLW disposal", Poster presentation 071, 29th International Symposium on the Scientific Basis for Nuclear Waste Management (MRS 2005), Ghent Belgium (2005).

[4] Poyet S., "Conception du superconteneur ONDRAF/NIRAS Phase 2: Simulation du comportement Thermo Hydrique du tampon en béton en service", Rapport Technique CEA DPC/SCCME 04 690, (2005), 21p.

[5] Sercombe J., Gallé G. and Ranc G., "Modélisation du comportement du béton à haute température: transferts de fluides et de chaleur et déformations pendant les transitoires thermiques", Note Technique CEA DPC/SCCME 081, (2001), 86p.

[6] Gallé C. and Sercombe J., "Permeability and pore structure evolution of silico calcareous and hematite high strength concretes submitted to high temperatures", Materials and Structures 34(244), (2001), pp. 619-628.

[7] Van Genuchten M.T., "A closed form equation for predicting the hydraulic conductivity of unsaturated soils", Soil Science Society of America Journal 44, (1980), pp. 892-898.

[8] Villain G., Baroghel-Bouny V., Kounkou C. and Hua C., "Mesure de la perméabilité au gaz en function du taux de saturation des bétons", Revue Française de Génie Civil 5(2-3), (2001), pp. 251-268.

[9] Waller V., "Relation entre composition des bétons, exothermie en cours de prise et résistance en compression", Book OA 35, Presses du Laboratoire Central des Ponts et Chaussées (2000). 